\title{
The Eighteenth Century Practice of Navigation As Recorded in the Logs of Hudson's Bay Company Ships
}

\section{William Glover}

La navigation s'est beaucoup améliorée au cours du dix-huitième siècle. Parmi ces améliorations, notons le développement d'instruments à réflexion, deux méthodes pour déterminer la longitude, une idée plus précise de la forme de la terre et des progrès importants en mathématiques pour soutenir ces progrès. Comment la pratique de la navigation a-t-elle tenu compte de ces changements? Les capitaines des navires de la Compagnie de la Baie d'Hudson étaient des hommes compétents près du sommet de leur profession, aptes à rapidement mettre en application certains développements mais pas d'autres, tels que l'adoption de nouvelles méthodes de déterminer la longitude en mer.

The tercentenary of John Harrison's birth was used as an occasion for publicizing and popularizing his development of the chronometer as a means of determining longitude at sea. ${ }^{1}$ While the navigation challenge may have been "solved," what was the actual impact of this development on the practice of navigation? For example, the Royal Navy did not issue chronometers as a matter of policy to all its ships until the $1860 \mathrm{~s}^{2}$ This seems the more remarkable when one remembers that it was the loss of Admiral Sir Clowdisley Shovel's squadron on the Scilly Isles that was an important incentive for the adoption in 1714 of the legislation that offered the longitude prize ultimately awarded to Harrison.

\footnotetext{
${ }^{1}$ The proceedings of the Longitude Symposium held at Harvard University were published by William J.H. Andrewes, (ed.) The Quest for Longitude, (Cambridge, Mass., 1996). The popular account of Harrison's work, Longitude by Dava Sabel, published by Penguin Books in 1995 was also a product of the symposium.

${ }^{2}$ Derek Howse, Greenwich Time and the discovery of the longitude, (Oxford, 1980), 72.
}

The Northern Mariner/Le marin du nord, XXVI, No. 2 (April 2016), 145-64. 
How might this seeming tardiness to use the long desired and anticipated means of determining longitude be explained? Was it unique or a response common to other important navigational developments? Is it in any way a reflection of the abilities of the men appointed in command, or a function of their circumstances? Or, despite all the fuss and attention both in contemporary scientific circles and by modern historians, at the end of the day was it really not all that important?

The archives of the Hudson's Bay Company (HBC), which itself did not provide chronometers to its ships before the $1820 \mathrm{~s}$, includes a large collection of ships's logs. These are augmented by some masters' journals of the early sloop voyages to the Bay and of trading voyages within the Bay. They offer a record of the actual practice of navigation. Additionally, through company records and other sources, much is known about many of their masters which provides some context for the navigation record. Through them, we can gain an appreciation of how the major navigational developments of the eighteenth century were adopted by the seamen of the day.

Throughout the century, on ocean passage masters calculated their daily position "by account." They took their "departure" from a prominent feature whose latitude and longitude they knew. At least every two hours the course and distance made good was recorded on a traverse board and in the log. Once a day this was refined to a bearing and distance from the previous calculated position. If the course made good had been true north or south, there was no change in longitude, and the distance made good provided the change in latitude. If the course made good had been true east or west, there was no change in latitude, and the distance made good represented the change in longitude. For every other course between the cardinal points both latitude and longitude would change. Traverse tables gave differences of latitude and of longitudes that were applied to the previous position, producing a new position by account. ${ }^{3}$ Until the development of lunar distances and

\footnotetext{
${ }^{3}$ Some writers have mistakenly suggested that the point of departure was used as the prime meridian (Norma J. Hall, “Ocean Crossings: Hudson's Bay Company Seafaring in a Northern North Atlantic World," Manitoba History, Winter, 2013, No. 71, 18; Catherine Ward and Dennis Wheeler, "Hudson's Bay Company ships logbooks: a source of far North Atlantic weather data," Polar Record, 48 (245), 170.) The error is easy to understand as masters regularly described east/west distance in terms of longitude made from their departure point. However, if it was plotted on a chart, the longitude scale would have been based on a common prime meridian, frequently London (St Paul's Cathedral). Greenwich as a prime meridian became important only with the increasing use of astronomical means for determining longitude, as the Nautical Almanac tables were based on the meridian of the observatory's main telescope. William Coats provided the longitude of Hoy, the customary HBC point of departure for the westbound crossing, based on London, $3^{\circ} 30^{\prime}$ west. He also provided distances between points within Hudson Strait and Hudson's Bay as a measure of longitude, such as Cape Diggs to Cape Resolution, $14^{\circ} 20^{\prime}$ east, or from the region to England, such as "Buttons Isles to Silly in twenty-two days, $59^{\circ} 30^{\prime} \mathrm{E}$ longitude." In a sailing vessel forced to tack before the wind, a difference of longitude would have been the most useful way to describe long distance to others. The Geography of Hudson's Bay, being the Remarks
} 
chronometers this was the only method of calculating longitude at sea. Every source of information for this calculation was a potential source of error. Therefore from time to time the master would try to "reconcile" his account. The navigational developments of the century were all intended to reduce errors.

As the new century opened the general state of navigation had not materially advanced from 1670, the year of the HBC charter, or even earlier. When in 1695 Samuel Pepys, by then retired from public life but still actively interested in navigation and related matters, wrote Edmund Halley (clerk of the Royal Society and a future astronomer royal) asking about "The Deficiency of present Navigation Methods," Halley "could but reiterate the old complaints: the obstinate clinging of masters to the plain chart, lack of training, lack of knowledge of currents and of the variation."

In 1700 navigators' instruments were little changed from those that John Davis (of Davis Strait) had required in 1594: "The instruments necessary for a skilfull seaman are a sea compass, a crosse staffe, a quadrant, an astrolabe, a chart, an instrument magneticall for the finding of the variation of the compasse, an horizontall plaine and sphere globe, and a paradoxall compass. ... But the sea compasse, chart and crosse staff are instruments sufficient for the seaman's use: the astrolabe and quadrant being instruments very uncertain for sea observations." 5 Curiously, Davis omitted a logline and a half minute sand glass. These were needed to determine the distance made good.

The charts used for the voyage to the Bay were probably those of John Thornton. In 1673 he had engraved "A New Mapp of the north part of America" which included information from Zachariah Gillam's voyage of 1668-69 to Hudson's Bay prior to the company's charter. ${ }^{6}$ In 1685 Thornton produced a manuscript map of the Bay for the company, which "would have provided him with as much data as possible on the characteristics of the coasts and various river mouths, including some soundings."7 "Around 1704" Thornton published a chart of Hudson Bay and Strait, extending east to Cape Farewell in Greenland and south to Newfoundland and Nova Scotia. This chart had two longitude scales: one based on the Lizard (in the English Channel between Land's End and Falmouth) was on

of Captain W. Coats, in many voyages to that locality between the years 1727 and 1751 edited by John Barrow, 1882. Reprinted Burt Franklin, (New York, nd), 93, 94, 99.

4 E.G.R. Taylor, The Mathematical Practitioners of Tudor \& Stuart England, 1485 - 1714, (Cambridge, 1954), 123.

5 John Davis, The seaman's secrets, first published 1595. Facsimile reproduction of the 1633 edition, (New York, 1992), "What instruments are necessary ...".

6 Jeanette D. Black, "Mapping the English Colonies In North America: The Beginnings," in Norman J.W. Thrower, (ed.), The Compleat Plattmaker: Essays on Chart, Map, and Globe Making in England in the Seventeenth and Eighteenth Centuries, (Los Angeles, 1978), 115-6.

7 Richard I. Ruggles, A Country So Interesting: The Hudson's Bay Company and Two Centuries of Mapping, 1670 - 1870, (Montreal \& Kingston, 1991), 26. 
the south the border, and the second based on Tenerife on the north border. ${ }^{8}$ (The use of Tenerife as the prime meridian began when it was the farthest known point to the west.) The scale was large enough that a noon position could be plotted daily. ${ }^{9}$

Shortly after the founding of the company, King Charles II initiated two things that were important to navigation in the following century. In 1673 at his express order a mathematical "side" that became the Royal Mathematical School was established at Christ's Hospital with the stated purpose of teaching boys the mathematics necessary for service at sea. ${ }^{10}$ Finding a suitable instructor was, however, a problem that was still not resolved as late as $1709 .{ }^{11}$ In 1675 he established the Royal Observatory in Greenwich Park. Its work would be directly involved with the problem of determining longitude.

As the new century opened, the company's relationship with the ships' commanders had not been without difficulties. A despatch in 1682 from John Nixon, the governor in the Bay, to the governor and committee in London, described Nehemiah Walker and Richard Tatnam, both ship masters, as drunkards whose conduct, but for good luck, could have hazarded their vessels. ${ }^{12}$ Of the early captains, Michael Grimington was the longest serving. He had entered the company's employ in 1680. In 1684 he crossed the Atlantic as a second mate with the understanding that he would be a sloop master in the Bay. He led an exploring expedition in 1686 and made his first trans-Atlantic voyage as a captain in 1690 . He died at the start of his twelfth voyage in command. While he was certainly a very good navigator, the same cannot be said of his son who also served the HBC. The assessment of the younger man is that "any reputation Grimington may have earned as a seaman was ruined by drunkenness." He was last employed as a chief mate in 1719. ${ }^{13}$ Second to the elder Grimington, James Belcher had the most trans-Atlantic commands, with ten return voyages between 1714 and 1724. Joseph Davis had commanded five voyages, but was not employed after 1715 when he failed to deliver his cargo. Richard Ward also made five voyages, but twice lost his ships and

\footnotetext{
${ }^{8}$ Kenneth A. Kershaw, Printed Early Maps of Canada, 1540 - 1703, (Ancaster, Ontario, 1993), 209-211.

${ }^{9}$ One degree of latitude, sixty nautical miles, equalled approximately two centimetres.

${ }^{10}$ The use of the word "hospital" may be confusing. Christ's Hospital was a charity school established in 1533. Until the royal order added mathematics, it taught grammar, writing, drawing and reading. Richard I. Ruggles, "Hospital Boys of the Bay," The Beaver, Autumn 1977, 7.

11 Taylor, 114-8.

12 John Nixon, Report to the Governor and Committee, in E.E. Rich, (ed.) Minutes of the Hudson's Bay Company 1679 - 1684, (London, 1945), Appendix A, 258-60.

${ }_{13}$ Alice M. Johnson, Michael Grimington, Dictionary of Canadian Biography, (Toronto, 1969) VII, 267.
} 
was not employed after 1719. When first hand knowledge and experience was an important part of navigation, the company's masters did not have great depth.

The oldest record of an HBC trans-Atlantic crossing is Peter Clements's account of his 1717 voyage as master of the Diligence, sloop. ${ }^{14}$ He styled it a journal, and used a narrative account rather than a log book format with the day ruled into at least two-hour periods. The latter, with its regular observations of course and distance made good, wind and weather, and other pertinent information, made it easier to reconstruct the day's work should it be necessary at some point in a crossing to check calculations. ${ }^{15}$ Michael Grimington Jr, who had served as chief mate under Joseph Davis on the 1713 trans-Atlantic crossing, had also used the journal format as a sloop master within Hudson Bay in $1715 .{ }^{16}$ (Davis served at least once as chief mate to the elder Michael Grimington on a trans-Atlantic crossing and succeeded him in command in 1710 when Grimington died before departing English shores.) The Diligence crossing is unremarkable. Clements regularly took the altitude of the sun at its meridian passage for his noon latitude, and compared it with his latitude by account. ${ }^{17}$ He would most probably have used a Davis backstaff. This was an instrument made of wood and, rather than observing the sun directly, which over time was hard on the eyes, used the shadow created by the sun on a crossbar on the instrument. On making landfall first at Cape Resolution at the eastern entrance to Hudson Strait and again at Cape Charles (Charles Island in Hudson Strait ${ }^{18}$ ) he took new points of departure for his running account. Restarting the account removed the accumulated errors of incorrect assessment of the course and distance made good.

Chance gave the company the opportunity to appoint three new masters over five years during the $1720 \mathrm{~s}$. First, the need for more cargo capacity led to the

14 B3/a/8, microfilm 1M3, Hudson's Bay Company Archives (HBCA), Provincial Archives of Manitoba, Winnipeg, Manitoba. A complete set of the microfilm is also available at the Library and Archives, Canada, in Ottawa, Ontario, and (with different numbers) at The National Archives, Kew, London, England.

15 For example, Captain Jonathan Fowler made a note of reviewing his calculations on 24 September, 1779. King George ship's log, C1/383, microfilm 2M36, HBCA.

${ }^{16}$ Grimington's journal B3/a/6, microfilm 1M3, HBCA. On his longer 1716 voyage he used a log format ( B3/a/7).

17 Navigators had long known that at "high noon" - when the sun is directly overheard - latitude can easily be determined. In technical language, it is the meridian passage, the crossing the observer's meridian of longitude, of the sun. On the HBC voyages, latitude was calculated by adding to the observed altitude of the sun, the declination of the sun above the equator which would have been available in tables provided in navigational books.

18 William Coats, The Geography of Hudson's Bay, being the Remarks of Captain W. Coats, in many voyages to that locality between the years 1727 and 1751 edited by John Barrow, 1882. Reprinted Burt Franklin, (New York, nd), 31, described Cape Charles as: "a cluster of islands ninety miles east from Cape Diggs, the northernmost of which is in latitude of $62^{\circ} 55^{\prime}$." In fact it is one large island ninety-seven miles east of Cape Diggs, and the northernmost shore is $62^{\circ} 44^{\prime}$. For the day, this was accurate. 
addition of a third ship for the 1722 voyage and George Spurrell was selected. He must have been recognized as a man of ability for, at the time of his appointment, he was the first master to be appointed in more than twenty years who came from outside the existing ranks of company servants. ${ }^{19}$ Although the committee minutes are silent, reaching outside the existing ranks of ships' officers may have been deliberate. ${ }^{20}$ Certainly the committee compensated for Spurrell's lack of local knowledge within the Bay with the careful selection of his mates. ${ }^{21}$ Ingram Gofton, a master of four voyages, died in January 1724. The committee decided not to make an immediate replacement. That season James Belcher lost his ship on Weston Island, and was not employed again. In January 1725 Christopher Middleton, most recently first mate to Spurrell, was selected from amongst internal candidates. ${ }^{22} \mathrm{He}$ was unquestionably the most scientific navigator the HBC employed in the century. For two years the company only sent two ships out to the Bay, but then the need for increased capacity again led to the addition of a third ship. On 23 November 1726 William Coats was appointed as a third new captain at $£ 6$ a month. ${ }^{23}$ Like Spurrell, he joined from outside the company ranks as a well qualified seaman. However he was obviously known to influential HBC people. His father-in-law had been governor in the Bay, but was in England supervising the construction of a new ship, the Mary, which would be Coats's command.

Coats lost his ship on his first outbound voyage. The Mary was caught in ice off Cape Farewell, Greenland, and crushed. For the 1728 voyage, a new ship of the

\footnotetext{
19 The one possible exception might be Richard Harle, master of the Union, that made one voyage only in 1714. The ship was chartered and modern practice for time charters, which may well have been current in the early 1700s, would suggest that Harle was appointed by the owners (J. Bes, Chartering and Shipping Terms, Amsterdam, 1951, 116). Governor Knight was embarked in the Union, and would have provided the otherwise absent local knowledge.

20 "The severall persons following having petitioned to serve ye Company as Commander of the New Ship now building viz. Mr Clements [previously master of the Prosperous, Diligence, and chief mate of the Port Nelson], Mr Jos Davis [succeeded Michael Grimington Sr as master for trans-Atlantic crossings, but not employed again after he failed to reach York in 1715], Mr Thos Lucas [had previously served as both second and chief mate], Mr James Napper [a carpenter who had served as master of the trading vessels out of Churchill] \& Mr Geo Spurrell having been severally heard, Mr Geo Spurrell was unanimously chosen commander of the new ship now building at Mr Taylor's Dock." London committee minutes 6 March 1721/22, A1/120, microfilm 14,HBCA.

${ }^{21}$ Peter Clements was appointed chief mate and George Green second mate. London committee minutes 10 April 1722, ibid.

${ }^{22}$ London committee minute 28 October 1724, A1/120, microfilm 14, HBCA; K.G. Davies, (ed.) Letters From Hudson Bay 1703 - 40, (London, 1965), 108n. The other candidates were: Henry Kelsey, a former governor in the Bay and master of the Prosperous, a trading sloop; George Kennedy a former chief mate to James Belcher and master of the Beaver; John Scroggs, master of the Whalebone for an exploring expedition in which he had failed to employ Christopher Middleton, and Francis Lilly.

${ }^{23}$ London committee minutes, 23 November 1726, A1/121, microfilm 14, HBCA.
} 
same name was built, and given to Spurrell, now the senior captain. Christopher Middleton moved into Spurrell's former ship, while Coats was given Middleton's former command, the Hannah. Coats was sent to Churchill. Quite apart from the trade, another result of the voyage was two manuscript charts he made of "The coast of Hudson Bay from Churchill south to the Nelson River" and of James Bay. They were both dedicated to Samuel Jones, a long serving and important member of the London committee who would be elected deputy governor the following year. ${ }^{24}$

During the 1730 s three new instruments were invented which offered significant improvements to the accuracy of observing the sun, and later, other heavenly bodies. The most famous of these was John Hadley's reflecting quadrant. Hadley, vice president of the Royal Society, developed his instrument in 1730, and presented it to the society the following year. Although the arc was only $45^{\circ}$, an eighth of a circle, using double reflection it could measure an angle of $90^{\circ}$. Hence it was known as a quadrant. It was smaller and easier to handle than a back staff. In time it would be made of metal, making it more durable and, when fitted with a vernier, significantly more accurate. One historian has suggested it did not come into common use for about twenty years. ${ }^{25}$ (The mathematical school at Christ's Hospital did not replace cross staffs and back staffs with Hadley's instrument until $1755 .{ }^{26}$ ) Cost may have been a reason for the slow adoption of Hadley's quadrant. Hadley applied for a patent for his invention in 1734, after it had been tested at sea. It expired in $1745^{27}$ but as late as 1757 well made quadrants of brass could cost as much as 126 shillings[£6/6/-]. A master's base salary was still $£ 6$ a month and in

\footnotetext{
24 "The coast of Hudson Bay from Churchill south to the Nelson River, dedicated to Samuel Jones, Esq, NMC VII/1101 - [1728], National Map Collection, Library and Archives of Canada, Ottawa, photocopy of a manuscript map in the Ministry of Defence, Hydrographic Department, Taunton, Somerset, 351/Ail [Great Britain, Admiralty, Hydrographic Department, Professional Paper No 13, (London, 1950). James Bay. Dedication: "To Samuel Jones Esqr. this chart of James Bay is ... dedicated and presented by William Coats 1728," NMC VII/1101-1728, photocopy of a manuscript map in the Ministry of Defence, Hydrographic Department, Taunton, Somerset, 351/Ail. These manuscript charts are of additional interest in that they are not mentioned in the Ruggles catalogues in A Country So Interesting. In other words, they escaped any mention in HBC records or minutes.

${ }^{25}$ A.N. Stimson, John Hadley and his Reflecting Quadrant, National Maritime Museum, Occasional Technical Paper No. 2 (1975), 3.

${ }^{26}$ Gloria Clifton, "The London Mathematical Instrument Makers and the British Navy, 17001850," in Pieter van der Merwe, (ed.), Science and the French and British Navies, 1700 - 1850, (Greenwich, London, 2003), 27.

27 W.E. May, A History of Marine Navigation, (New York, 1973), 145.
} 


\section{1 a chief mate was paid $£ 4$ a month. ${ }^{28}$ Officers provided their own instruments, ${ }^{29}$} and for the mates this might have been beyond their means.

Caleb Smith also made a reflecting instrument in 1734 that became available the same year. It had the advantage that a bubble could be fixed to it, thus providing for an artificial horizon. ${ }^{30}$ It was made for Smith by Thomas Heath, "one of the most notable instrument makers of the first half of the eighteenth century." In his advertisement for Smith's quadrant, he noted that it was approved by Captain Christopher Middleton, Captain George Spurrell, and Joseph Harrison, "all experienced navigators." ${ }^{31}$ This offers interesting evidence of the readiness of Middleton (who had already presented two papers to the Royal Society), but more importantly Spurrell as well, to test new instruments. Obviously their professional standing was such that Heath thought it useful to publish their endorsement.

${ }^{28}$ Clifton, 28; London committee minutes, 20 February 1751, A1/38, microfilm 4, HBCA.

${ }^{29}$ I do not agree with the suggestion that the company paid for officers' navigational instruments.

(Michael F. Dove's PhD thesis, "Shipping on the Edge of the Atlantic World: The Maritime Dimension of the Hudson's Bay Company, 1668-1774," University of Western Ontario, 2007.) Dove says that the company "consistently equipped their ships's captains with new instruments" and that Hadley's reflecting quadrant was provided as soon as it was available (43)). First, the evidence offered is insufficient. The London committee minute of 13 May 1730 ( A1/143, microfilm 17, HBCA), ordered that "a gratuity of five pounds be given to Capt. Middleton towards the charge he has been at in furnishing himself with several instruments useful in navigator and his trouble and expense in procuring" is not the consequence of a policy to provide instruments, but rather of a generous practice of paying gratuities to company masters for a wide range of things. Were instruments provided as a policy, the minutes would reflects more numerous payments of full reimbursement for other officers. Rather, this is a unique payment to an individual widely regarded by historians as being exceptional. Second, a distinction is properly made between ship's equipment and personal instruments. Payments for compasses (or log lines and sand glasses) were for ship's equipment. A.E. Fanning in Steady As She Goes: A History of the Compass Department of the Admiralty, (London, 1986) noted that following the 1707 Clowdisley Shovel disaster, only brass bowl compasses would be provided to ships, instead of compasses with other types of bowls. However, some navigational equipment was a personal responsibility. Sir Byam Martin noted that it was only after the Napoleonic Wars that the Royal Navy began to supply chronometers to its ships at public expense. (Sir Richard Vessy Hamilton, (ed.), Letters and Papers of Admiral of the Fleet Sir Thomas Byam Martin, (London, 1903), 124). Captain Leckie is quite explicit: "The navigator who takes a proper pride in his work should possess a first-class sextant or Quintant and a good octant." (Wrinkles in Practical Navigation, first published 1881, seventeenth edition London, 1915, 69). He then goes on to advise on how to purchase a sextant. Third, it is a mistake to assume that new developments to inventions are adopted immediately. (Samuel Eliot Morrison, The European Discovery of America (2 vols, New York, 1971 \& 1974), I:141, II:x.) George Spurrell did not record using a Hadley. And of course the company was slow to use chronometers. Item 1912-392 at the Science and Industry Museum, Kensington, is a backstaff "Made by Jonathan Gilbert, Tower Hill, London, for Henry Tyndall, January 20, 1759." Navigators used, and use, what they believe they need.

${ }^{30}$ Charles H. Cotter, A History of the Navigator's Sextant, (Glasgow, 1983), 127-9.

${ }^{31}$ E.G.R. Taylor, The Mathematical Practitioners of Hanoverian England 1714 - 1840, (Cambridge, 1966), 192. 
Unfortunately the ships' logs of trans-Atlantic voyages before 1751 do not survive. However Spurrell's logs from that year until 1756 when he was elected to the London committee and retired from the sea recorded his continuing occasional use of a "Smith" for his noon observation.

The third important new instrument used for noon observations was an Elton the instrument Moses Norton, the governor of Prince of Wales Fort provided Samuel Hearne for his overland journey to the Arctic Ocean. This was also developed in 1730, and described in the Royal Society's Philosophical Transactions in 1732. John Elton, about whom little is known except his instrument, fitted levels to the Davis backstaff. So modified, it was the first observing instrument to use an artificial horizon. It was criticized as being "no better than Davis's quadrant except in hazy weather or at night." 32 One historian writes, "there is no evidence that it [Elton's instrument] was ever adopted as a practical solution [to the lack of a visible horizon]. ${ }^{33}$ Hazy weather was a common occurrence on the passage to Hudson Bay, and the use of an Elton by Spurrell and most subsequent captains was frequently recorded with the noon observation.

Hadley's quadrant offered a level of precision that clearly appealed to Middleton and his scientific interests. He recorded its use when he took observations for longitude in the Bay on 8 September 1736. This was only the second longitude to be determined within Hudson's Bay. ${ }^{34} \mathrm{He}$ was on his return voyage from Moose Factory. "Being in Hudson's-Bay, in the Latitude 55 Degrees 34 Minutes North, and on the meridian of the North-Bear-Island, which lies 30 Miles to the Westward of Charlton island, I observed a total eclipse of the Moon." This produced a longitude of $79^{\circ} 51^{\prime}$ west of London..$^{35}$

At short notice in 1741 Middleton left the HBC to accept a commission in the Royal Navy as a captain. He had been offered command of an expedition to search the west coast of Hudson Bay for a northwest passage. He made a second observation for longitude while wintering at Prince of Wales Fort, 1741-42. Using

\footnotetext{
32 Cited in ibid, 175.
}

33 Cotter, 189.

34 The first was by Thomas James, who gave his name to the bay. He wintered over in 1631-32 on Charlton Island. While there he observed an eclipse of the moon, which when reduced gave a longitude of $79^{\circ} 30^{\prime}$ west of London. This calculation was extremely accurate. Miller Christy noted that the Admiralty's longitude of James's wintering location was $79^{\circ} 15^{\prime}$. The Sailing Directions, Labrador and Hudson Bay, sixth edition, (Ottawa, 1988), 382, gives the longitude for Charlton as $79^{\circ} 27^{\prime}$ W. Miller Christy, (ed.), The Voyages of Captain Luke Foxe of Hull and Captain Thomas James of Bristol in Search of a Northwest Passage, in 1631-32. Hakluyt Society, in two volumes, 1894, Burt Franklin reprint, (New York, nd), II, 612-19.

${ }^{35}$ Capt. Christopher Middleton, FRS, "An Observation of the Eclipse of the Moon, Sept. 8, 1736, made in Hudson's Bay," Philosophical Transactions, 40, 96-98. The modern value is $81^{\circ} 06^{\prime} \mathrm{W}$ (Sailing Directions: Labrador and Hudson Bay, (Ottawa, 1988), 384), but on chart 5003, Hudson Bay (Southern Portion) and James Bay, Canadian Hydrographic Service, 1976, the island is marked as "position approximate." 


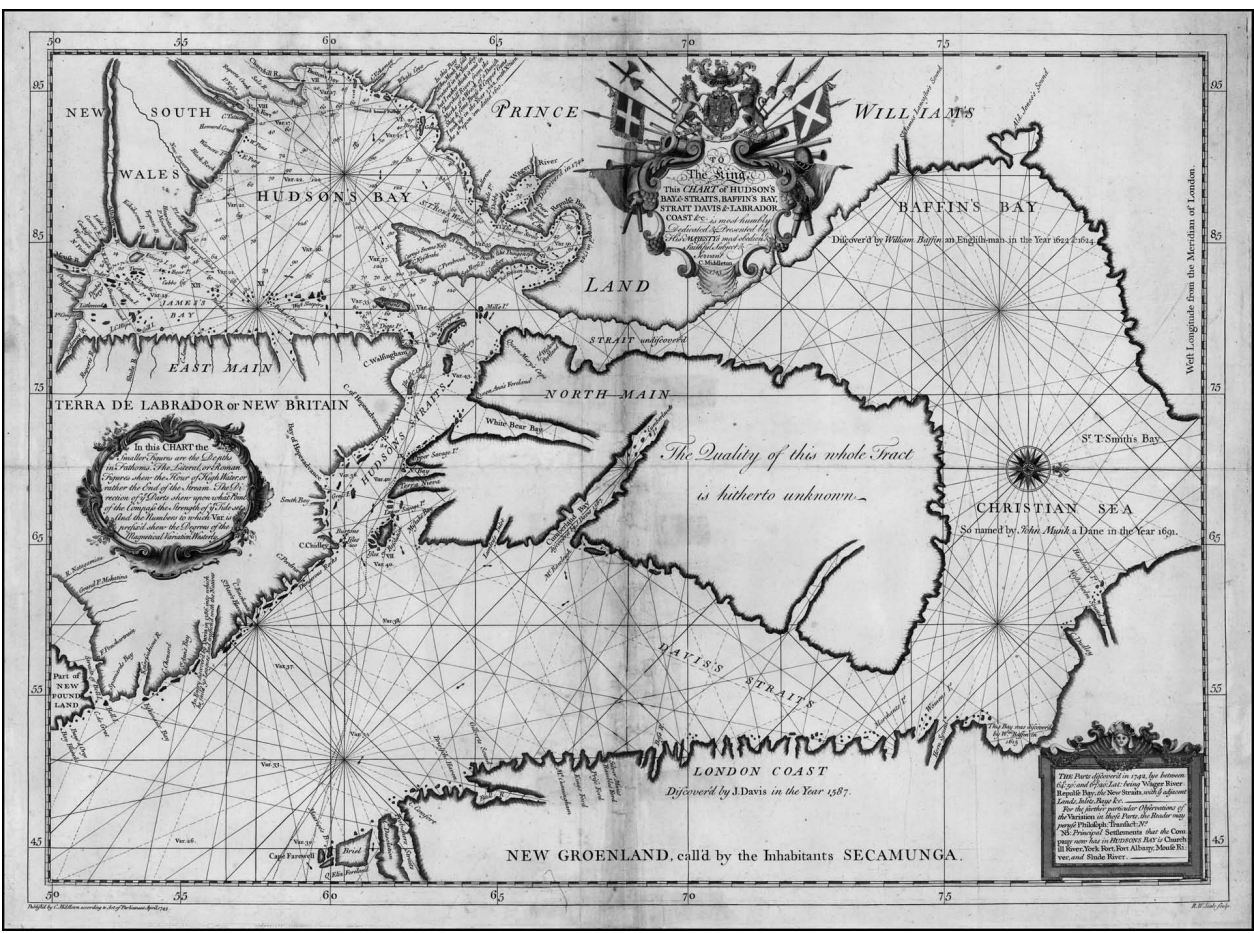

C. Middleton, Chart of Hudson's Bay \& Straits, Baffin's Bay, Strait Davis \& Labrador Coast, etc. 1743

Jupiter's satellites, his value was $94^{\circ} 50^{\prime} \mathrm{W}$ of London. It is in error by about $45^{\prime} \mathrm{W}$, but before passing judgement remember that on 20 March 1742, when he made it, the weather was "Fresh Gales with some Snow in the Night, and Very Cold Freezing Weather." 36 The Royal Society, to whom he read a paper on his return about "The Extraordinary Degrees and Surprizing Effects of Cold in Hudson's Bay, North America," thought sufficiently well of his work to award him their Copley Gold Medal.

Middleton's expedition was unsuccessful in finding a passage, a result that the principal proponent was unwilling to accept. Unfortunately for Middleton, the controversy about what might or might not have been done degenerated into an unpleasant pamphlet war. However Middleton did produce a new chart of Hudson Bay and area that has been described as "the first improvement in arctic cartography" of the eighteenth century. ${ }^{37}$ Its longitude scale was based on London.

${ }^{36}$ Commander J.B. Hewson, A History of the Practice of Navigation, (Glasgow, 1983), 232;

William Barr and Glyndwr Williams (eds.) Voyages in Search of a Northwest passage 1741 - 1747, Volume 1, “The Voyage of Christopher Middleton 1741 - 1742," (London 1994), 156.

${ }^{37}$ Kenneth A. Kershaw, Early Printed Maps of Canada, Volume 2, “1703 - 1799," (Ancaster, Ontario, 1996), 63. 
In 1749 Coats had been ordered by the London committee to prepare some charts of the east shore of Hudson's Bay. ${ }^{38}$ They do not include longitude information. Nor did the 1740 plan of the entrance to Moose River by George Howy, although it did have soundings, detailed sailing directions, and tidal information. ${ }^{39}$ The absence of a longitude scale or information would not have been considered a deficiency. In 1750 Murdoch Mackenzie published an atlas of charts of Orkney and the Lewis islands. "Based on a rigid triangulation framework for the first time," his work "was to prove the most accurate and detailed marine survey yet attempted in the British Isles." 40 The text includes neither latitude nor longitude information, as today is commonplace in sailing directions, and the chart of Orkney also lacks longitude information. ${ }^{41}$ A possible explanation could be that the charts of Thornton and Middleton mentioned above were used for ocean passages, on which the noon positions were plotted (or pricked). Coats's manuscript charts were probably intended as information for the London committee, rather than for use at sea. Regardless, like Murdoch Mackenzie's charts they were larger scale charts of a smaller area. A navigator using them would obviously have been in sight of land, and therefore longitude information would have been of little if any value.

Coats had one other work which, while it may never have been used for assisting navigation, is nonetheless of great interest in the history of Hudson Bay navigation. An important part of the equipment of navigation was first hand experience, either one's own, or that of mates, and was sometimes supplied in the form of log books of earlier voyages. Coats probably hoped that like the Spurrells or the Fowlers, he might be able to promote a son in the company's service. Certainly in one instance an exception was made and he was permitted to appoint a son as a third mate. ${ }^{42}$ To assist his sons in the ranks of company navigators, he wrote down the sum of his years of experience going to the various factories in the Bay. That employment never came to pass. The full history of his manuscript will never be known; certainly for a while it seems to have been lost, but in the nineteenth century John Barrow the famous supporter of Arctic endeavour at the

\footnotetext{
38 These manuscript charts are available only in the HBCA at Winnipeg. They are G1/18, G1/15 and $\mathrm{G} 1 / 16$.

${ }^{39}$ G1/117, HBCA, Winnipeg. Ruggles, A Country So Interesting, 35, describes George Howy as the sloop master at Moose Factory. He does not appear to have served as a mate, let alone a master, on a trans-Atlantic crossing. Davies, (236n) describes him as "second \& accomptant" at Moose Factory. Given the short navigation season in the Bay, the two are not inconsistent.

40 A.H.W. Robinson, Marine Cartography in Britain, (Leicester, 1962), 60.

${ }^{41}$ Murdoch Mackenzie, Orcades, or a Geographic and Hydrographic Survey of the Orkney and Lewis Islands in eight maps, London, 1750, and "The South Isles of Orkney," G5/3, map 2, HBCA, Winnipeg. The HBCA copy of Orcades is annotated, "Belonging to the Hudson's Bay Company for the use of their ship Sea Horse, May Anno 1751, Chas. Hayes, Secretary."

${ }^{42}$ London committee minute 7 April 1748, A/37, microfilm 4, HBCA.
} 
Admiralty, edited it for publication with the Hakluyt Society. ${ }^{43}$ So today we have a compendium of what was deemed useful and important knowledge for navigation in the Bay.

Meanwhile, one of Coats's mates, John Fowler, had been appointed in 1744 to succeed Middleton. Fowler obviously had some ability and experience, for in 1740 he was paid $£ 6$ for piloting the Mary from Yarmouth up the Thames to the Pool of London. ${ }^{44}$ In 1744, after three years of only two ships making the crossing, the number was increased to three plus a pink, ${ }^{45}$ named Hudson's Bay V. This was commanded by Jonathan Fowler, a brother of John. In 1750 John Fowler announced his intention to leave the HBC to buy a ropewalk. He was quickly replaced by Jonathan. Joseph Spurrell, chief mate to his father since 1741, was appointed to the Hudson's Bay. Coats was dismissed the company's service at the conclusion of the 1751 voyage on the charge of having engaged in the private trade of spirits. Joseph Spurrell was then moved into a ship, and William Norton, first employed as a second mate to George Spurrell in 1744, took command of the pink. When George Spurrell was elected to the committee after the 1756 voyage, William Norton moved into a ship and Jonathan Fowler Jr, who had been secant and then chief mate to his father, succeeded in Hudson's Bay. A brief period of command stability then ensued. In February 1764 Joseph Spurrell asked to be allowed to serve ashore in any capacity, so Joseph Richards, who since 1751 had been second and then chief mate under Spurrell, was appointed in command. This chain of succession in command suggests two things. First, the committee had clearly been satisfied with the navigational competence and professionalism of Spurrell, Middleton and Coats. Men they trained were promoted. Second, all the new captains had experience in the Bay, and "knew the route." This practice of promoting mates to command continued for the balance of the century.

Although the technology for noon sights did not materially change, developments in mathematics offered an alternative to the observation of the meridian passage (merpass) of the sun for latitude. In 1769 Joseph Richards started using "latitude by two altitudes." A Dutch mathematician and navigation instructor, John Douwes, developed a set of tables about 1740 that allowed for the calculation of latitude by double altitudes of the sun. They remained in manuscript form, but "Copies thereof [came] into the hands of several English officers who held them in

\footnotetext{
43 The Geography of Hudson's Bay, being the Remarks of Captain W. Coats, in many voyages to that locality between the years 1727 and 1751 edited by John Barrow, 1882. Reprinted Burt Franklin, (New York, nd).

${ }^{44}$ London committee minutes 1 October 1740, A1/35, microfilm 3, HBCA.

${ }^{45}$ A ship had three square rigged masts. A pink, as defined by the HBC, also had three masts, but the mizzen had a lateen sail rather than being square rigged. E.E. Rich, The History of the Hudson's Bay Company 1670 - 1870, (London, 1958), I 36n.
} 
high esteem." ${ }^{46}$ Dr Henry Pemberton, ${ }^{47}$ a fellow of the Royal Society, obtained a copy and refined the method of finding the latitude. On 20 November 1760 he read his paper "Some Considerations on a late Treatise intituled, "A new set of Logarithmic Solar Tables \&c.' intended for a more commodious Method of finding the Latitude at Sea, by Two Observations of the Sun." It was subsequently published in the Philosophical Transactions. ${ }^{48}$ John Robertson, an FRS since 1740, and variously master of the Royal Mathematical School at Christ's Hospital in London, the head master of the Royal Academy at Portsmouth, and ultimately librarian of the Royal Society, included seven methods other than merpass of finding the latitude by observation in the second edition of his Elements of Navigation appearing in $1764 .^{49}$

In 1768 the HBC provided transportation to Prince of Wales Fort at Churchill in Richards's ship for two astronomers nominated by the Royal Society who were to observe the 1769 transit of Venus. They were William Wales and his assistant, Joseph Dymond. Wales had been a "computer" working on the tables for the Nautical Almanac, developed by the astronomer royal, Nevil Maskelyne, and first published for the year 1767. Dymond had been an early assistant to Maskelyne at the Greenwich observatory. ${ }^{50}$ On the westbound voyage Richards went from 14 July in the Atlantic to 24 July, when he was in Hudson Strait, without an observed merpass latitude. The difficulty this presented should not be under estimated.

The importance of an observed latitude was described in a 1777 Treatise on Practical Seamanship. "The latitude when it can be got by a good observation, with a good instrument, must be allowed to be the only sure guide we have in navigation; because it not only gives to a certainty the ship's place, north and south, but it likewise helps us to form a judgement how far a dependence may be put on our reckoning East or West, in proportion as the latitude by the account kept of the ship's way agrees or disagrees with the latitude observed in the passage in general; so more or less dependence accordingly may be put upon the longitude reckoned to

\footnotetext{
${ }^{46}$ Charles H. Cotter, A History of Nautical Astronomy, (London, 1968), 148; John Robertson, Elements of Navigation $3^{\text {rd }}$ edition, (London, 1772), 324.

47 b. 1694, d. 9 Mar 1771. He qualified as a medical doctor at in Leyden 1719. When he was elected an FRS on 30 November 1720, one of his sponsors was Edmond Halley who had been appointed the astronomer royal in February 1720.

48 Philosophical Transactions 51, 910-929.

49 The methods were: 1. By declination and zenith distance [merpass]; 2. By declination and equal altitudes; 3. By 3 zenith distances at equal intervals near noon; 4. By 3 zenith distances at unequal intervals near noon 5; By 3 zenith distances at equal intervals not near noon; 6. By 3 altitudes at unequal intervals not near noon; 7. By 2 altitudes, the interval of time, declination and latitude by account; 8. By declination, two altitudes, the interval of time, latitude by account and course and distance run between the observations.

${ }^{50}$ Derek Howse, Nevil Maskelyne: The Seaman's Astronomer, (Cambridge, 1989), 60, 86.
} 
be in." ${ }^{51}$ When the difference between the latitudes by observation and account was significant, the master would try to reconcile the account by identifying a probable source of error, and then determining a correction to be applied.

Solving longitude would reduce and ultimately remove the dependence on a position by account. An appreciation of the full extent of the source of error in the account would seem to make more curious the apparent tardiness to adopt new methods of determining longitude. As an account began with a point of departure, so a review or errors might start there.

Navigation manuals of the period all had long lists of "established positions" that could be used as a point of departure. James Green, in his Remarks in Support of the New Chart of North and South America in Six Sheets, noted that apart from the longitude for Churchill observed by Middleton, astronomical observations for latitude and longitude on the east coast of North America had only been made at Boston, New York and New Orleans. The exact position of Cape Farewell at the southern tip of Greenland, an important way point for the HBC voyages, was problematic. Green wrote, 'I place it in Longitude $26^{\circ} 30^{\prime}$ which is 30M. more west than Mr D'Anville places it; But 1 ${ }^{\circ} 30^{\prime}$ more East than by Mr Bellins's Map of the World, and 50 Minutes more East than by his Chart of the North Seas. Captain Middleton puts Cape Farewell one Degree more East; and Mr Egede $2^{\circ} 20^{\prime}$ more West than I have done." ${ }^{52}$ Green offered a similar discussion for places within Hudson's Bay. Thus the point of departure for any position by account was likely incorrect.

The distance made good was a function of speed and time. It was determined by casting a log line and counting the number of knots in the line that ran out during a for a thirty second period measured by a sand glass. Both the line and the glass were sources of error. Were the knots in the log line correctly spaced? In the seventeenth century there has been considerable debate about the length of a nautical mile. Although an extremely accurate measurement had been provided in 1637, many masters preferred to use a line knotted to measure a mile of a different length. Some thought it safer "to keep the reckoning ahead of the ship." As late as 1764 at least one navigation manual was saying, that the log line should have the knots at forty-six foot intervals. It went on, "in strictness each knot should be about 50 feet; but it is better to be only 45 or 46, and this agrees best with experience, for the log will drag a little bit after the ship, and make the measured distance less than

\footnotetext{
${ }^{51}$ William Hutchinson, A Treatise on Practical Seamanship with Hints and Remarks relating thereto ..., (Liverpool, 1777), 80-81.

${ }^{52}$ (London, 1753), 7, 9. Green's Cape Farewell longitude, based on Tenerife with the modern longitude of $16^{\circ} 35^{\prime}$ west of Greenwich, would give a longitude of $43^{\circ} 05^{\prime}$. The modern value for Cape Farewell is $43^{\circ} 30^{\prime}$.
} 
it is, and it is better the reckoning be ahead of the ship, than the ship be ahead of the reckoning." 53

In 1759 Jonathan Fowler, master of the Prince Rupert, recorded, "This is the worst account we have kept in sixteen voyages. Find the fault to be part in the log line." In 1782 his son, Jonathan Fowler Jr, then the senior HBC master, complained in his log on making landfall off Resolution, "This is the worst account I have kept ever since I can remember. Our time glass must be short or the log line is marked improperly." The year before he had made a similar complaint about the lines to the committee. ${ }^{54}$

The sand glasses used to measure the timing of the streaming of the log were also a source of error. Although a new technology for making sand glasses came into use during the eighteenth century, they remained essentially unchanged over the period. ${ }^{55}$ Was the glass properly timed? Captain John Horner ${ }^{56}$ of the Sea Horse in 1765 noted: "This error in latitude [between his observation and his account] I impute to our glass being short, which has made our distance shorter than what we have sailed. ${ }^{, 57}$ In museum conditions I found one sand glass that gave a different time each time the same bulb was being emptied. ${ }^{58}$ This was probably the result of imperfections in the interior surface of the glass. At sea, moisture would also affect the smooth running of the sand.

The recorded course made good was also subject to several different errors. The officers of the watch may not have supervised the helmsman closely enough, or made adequate allowance for leeway. (That is the difference between the course being steered and the course made good because the force of the wind was pushing

\footnotetext{
${ }_{53}$ William Emerson, Navigation or the Art of Sailing upon the Sea, (London, 1764), 5-6.

${ }^{54}$ Prince Rupert log entry 26 June 1759, C1/876, microfilm 2M 90, HBCA; King George log entry 1 August 1782, C1/386, microfilm 2M 36, HBCA. A previous complaint was noted in the minutes of the London committee on 19 December 1781. "Upon the complaint of log and lead lines and by the recommendation of Captains Jonathan Fowler and William Christopher, the person marking of the same in Whitechapel was ordered to attend the committee after the recess, and the captains to give him notice thereof." Rough Minute Book, A1/141, microfilm 17, HBCA.

${ }_{55}$ The earliest sand glasses, known as "Type A" were made of two bulbs, blown separately, with a narrow neck ending in a flange. The two were bound together with ribbon held in place by the flange. The next generation of sand glasses, Type B, were blown as a unit and had a small hole in one end for filling the sand. This was then sealed. Dates for the introduction of this type vary between the early and mid eighteenth century. (I am indebted to the staff of the National Museum of Science and Industry Museum, Kensington, London, for showing me their sand glass collection and explaining the method of manufacture to me.)

${ }^{56}$ Appointed in command 14 December 1763 following the death of William Norton. He returned from the Bay in 1748, rated as a second mate, and was appointed chief mate to Jonathan Fowler Sr in 1749. He had been an unsuccessful applicant for command in 1757 when Jonathan Fowler Jr was appointed.

57 Sea Horse log entry 1 September 1765, C1/1035, microfilm 2M 122,HBCA.

${ }_{58}$ Item 1991-240, National Museum of Science and Industry, 5 February 2001. This was a Type B sand glass, probably from the second half of the eighteenth century.
} 
the ship sideways through the water as it moved ahead. ${ }^{59}$ ) So, in 1764 when Captain Horner in the Prince Rupert was reconciling his account with the observed latitude, he wrote, "This error I impute to neglect of the courses so corrected my longitude accordingly." ${ }^{\prime 0} \mathrm{~A}$ second source of error, which would also affect the distance made good, was current. Masters regularly noted in their log an assessment of current based on a difference between latitudes observed and by account, and settled on a correction factor as a result. ${ }^{61}$ Finally, the manufacture of the compasses were at best poor, ${ }^{62}$ and the errors were not understood. It was only with the work of Captain Matthew Flinders, RN, in the early 1800s that it was recognized that a separate correction was required for deviation, not only unique to each ship but changing with the course, as distinct from the magnetic variation of an area of the globe. So, in 1751 Joseph Spurrell in his first command noted, "I find there is about half a point difference between our compasses and those of the other ships, we being obliged to steer half a point northerly to keep company." ${ }^{163}$ What did he record for his course made good? Assuming the traverse tables were correctly calculated, entering then with an incorrect course made good would create errors in the differences of latitude and longitude. On that voyage, the first day out from Hoy, (the common point of departure after topping off water and supplies at Stomness in the Orkneys), the young Spurrell made his longitude $2^{\circ} 50^{\prime}$ west of Hoy, while the experienced Captain Coats reckoned he was only $2^{\circ} 24^{\prime}$ west of the island. ${ }^{64}$

This sort of discrepancy was common. As a voyage progressed the discrepancies could be considerable. Captain Jonathan Fowler Jr, five days out from Resolution, recorded on 26 July 1782, "Spoke the other captains. Found they were between 30 and 40 leagues further to the westward than my account ...."65 Each master recorded a range of differences of longitude between the same places over a succession of voyages. On westbound crossings Captain Jonathan Fowler Jr had a range of longitude difference for the passage from Hoy to Resolution of just over $3{ }^{\circ}{ }^{66}$ Captain William Christopher's difference of longitude over the same route

\footnotetext{
59 Archibald Patoun, A Complete Treatise of Practical Navigation, $3^{\text {rd }}$ edition, (London, 1747), 314-6, provides a discussion of how much to allow depending on the strength of the wind and how close to it the ship is sailing.

${ }^{60}$ Prince Rupert log entry 29 September 1764, C1/886, microfilm 2M 91, HBCA.

${ }^{61}$ Lieutenant Matthew Fontaine Maury, USN, published the first wind and current chart of the North Atlantic in 1847.

${ }^{62}$ "At the start of the nineteenth century the state of compasses at sea was generally deplorable with weakly magnetized needles and very poor craftsmanship." A.E. Fanning, Steady As She Goes: A History of the Compass Department of the Admiralty, (London, 1986), xi.

${ }^{63}$ Hudson's Bay (pink) log entry 29 June 1751, C1/346, microfilm 2M31, HBCA.

${ }^{64}$ Hudson's Bay (pink) log entry 11 June 1751, ibid; King George log entry 11 June 1751, C1/360, microfilm 2M 32, HBCA.

${ }^{65}$ King George log entry, 26 July 1782, C1/386, microfilm 2M36, HBCA.

${ }^{66}$ King George log entries 28 July 1776, C1/380, microfilm 2M35, and 27 July 1764, C1/368, microfilm 2M33, HBCA.
} 
varied by $4{ }^{\circ} \cdot{ }^{67}$ Coats reported, "in the ordinary practice, we make $3^{\circ} 45^{\prime}$ of longitude more home than outward bound from London," 68 At best, longitude information could only be a guide for the navigator. It provided a warning of when the lookout for land should be increased. (Hence some argued it was better to keep the reckoning ahead of the ship.) So we find for example Captain Joseph Richards writing, "by my Longitude I should be abreast of the Lizard but am certain to the contrary by my soundings." 69 By comparison, Christopher on his last voyage in 1788, when making landfall off the Start, between Plymouth and Dartmouth in the English Channel, made a rare comment. "A very fine account within 4 or 5 leagues of the real distance." $" 70$ It was indeed time to retire.

With the potentially significant discrepancies of position between ships in company, even if the source of error was not fully appreciated, the need to reconcile position was. Hence an observed latitude as a check on all the calculations that went into determining the ships's position by account, was not just important, but a necessity. Richards's problem of going ten days without a merpass observation can be better appreciated. Is it too much to suppose that the astronomers showed Richards the methods of working up a latitude by other than a merpass observation?

The winter of 1768-9 was put to good use by at least Joseph Richards and his fellow captain, Jonathan Fowler. The voyage of 1769 saw them both using calculated methods to determine their latitude. Fowler on 4 July 1769 noted, "lat per 2 altitudes according to Mr Harrison's method." Richard Harrison was a mathematics teacher "well known to seamen as having published from a Dutch MS the logarithmic solar tables calculated by Cornelis Douwes of Amsterdam (1740) for finding the latitude by two extra-meridian observations and the elapsed time." 71 On 24 September, just five days before Fowler anchored in the Thames at Ratcliff Cross by the HBC warehouse, he wrote in his journal: "I have taken great pains in the course of this voyage to make trial of Mr Harrison's method of finding the Latitude by 2 Altitudes and have found it equally just and true with the Meridian observation and I really think it the greatest help \& improvement in navigation that

\footnotetext{
67 Sea Horse log entries 23 July 1778, C1/1043, microfilm 2M123, and 28 July 1781, C1/1046, microfilm 2M124, HBCA. Appointed in command of Sea Horse II for the 1770 voyage, Christopher had been in command of Churchill, sloop, for an exploring expedition in the Bay, 1761 and 1762, and otherwise had served as second mate to Jonathan Fowler Jr.

68 Coats, 11.

${ }^{69}$ Prince Rupert log entry 13 October $1767, \mathrm{C} 1 / 889$, microfilm 2M 92,HBCA.

${ }^{70}$ King George log entry, 29 September 1788, C1/391, microfilm, 2M 37, HBCA.

71 King George log entry, 4 July 1769, C1/373, microfilm 2M34, HBCA; Taylor, Mathematical Practitioners Hanoverian England, 233. Whatever Richard Harrison published does not appear to have survived, for there is no mention of him in Thomas R. Adams and David W. Waters, English Maritime Books Printed Before 1801, (Providence, Rhode Island, and Greenwich, England, 1995).
} 
has been made Publick since I have used the Sea."72 In subsequent voyages Richards, Fowler and other masters recorded latitudes by two altitudes or by ratio.

In contrast to Fowler's endorsement and the HBC record of use, it is interesting to note that one modern and widely used navigation text says that "a method involving two sights taken with a considerable time interval between, had previously been known, but the mathematics were so involved that it is doubtful that many seamen made use of it." 73 There is disagreement amongst navigation historians about its use. ${ }^{74}$ Clearly the company's masters used these methods for calculating latitude. Further, it is reasonable to argue that they would not have done so had they not felt the need.

During the 1768 voyage when Wales and Dymond probably discussed the Douwes methods of finding a latitude, they did show Richards the recently developed method of determining longitude by lunar distance. He assisted them as an observer when they took lunar distances. ${ }^{75}$ However, Richards did not use the longitude so determined in his log, and he never otherwise took lunar distances. Why would that have been? While one modern historian may argue that the tables in the Nautical Almanac, (which Wales had helped tabulate), reduced the time to about half an hour, ${ }^{76}$ William Hutchinson, the author of the 1777 A Treatise on Practical Seamanship and a Liverpool dockmaster, wrote "I speak for myself and many masters of ships, who can conduct a ship to any part of the world, that hath its latitude and longitude laid down, without having learned so much astronomy at school, as to understand the characters, signs and times \&c, that are used I those Almanacks." An error of one minute in an observation could result in a longitude error of a fifteen minutes. That, with what he considered the long calculations, made lunar distances an impractical method. ${ }^{77}$

\footnotetext{
${ }^{72}$ King George log entry, 24 September 1769, C1/373, microfilm 2M34, HBCA.

73 Bowditch, The American Practical Navigator, (Washington, 1962), 43.

${ }^{74}$ Commander J.B. Hewson commented on the utility thus: "It was during the latter half of the eighteenth century that a variety of other methods were advocated for the finding of latitude without relying upon the meridian altitude of the sun or other celestial body. ...The calculation, however, was long and tedious, and there is little evidence that this method, or several of the others suggested, were used, except possibly by a few, when the weather prevented them from resorting to the simpler methods." A History of the Practice of Navigation, (Glasgow, second edition 1983), 112. On the other hand, Cotter says Douwes's method "became very popular among British navigators." History of Nautical Astronomy, 148.

75 William Wales, "The Journal of a Voyage made by Order of the Royal Society, to Churchill River, on the North-west Coast of Hudson's Bay; of Thirteen Months Residence in that Country; and of the Voyage back to England; in the Years 1768 and 1769," Philosophical Transactions, 1770 , records Richards as an observer on 5 July 1768. Dymond recorded Richards as an observer for the altitude of the moon on 6 July. Churchill Voyage 1768 \& 1769, [Dymond's notebook], Codex Eng 53, John Carter Brown Library, Providence, Rhode Island.

${ }^{76}$ Howse, Greenwich Time, 66. To provide context, when I was a navigator at sea, it took me about twenty minutes, using tables, to reduce my observations of four stars to a position on a chart.

77 Hutchinson, 85-6.
} 
Observations for lunar distance required three skilled observers: one each to take the altitude of the moon and the sun, or other star from which the distance was being taken, and the third to take the horizontal distance between the moon and the sun or star. Even with skilled observers, there could be problems. William Wales recorded that on 8 August he and Dymond did observations for longitude. They differed by $31{ }^{\prime} \cdot{ }^{78}$ An HBC ship routinely had only a master and two mates. The second mate could not be expected to be a skilled observer. Further, as noted above, officers provided their own instruments. A good reflecting quadrant or sextant (which being able to measure angles of up to $120^{\circ}$ was much better suited) would have probably been beyond the means of a second mate, and possibly a chief mate.

Arguably the HBC masters did not need lunar information, The safety record of the annual voyages was impressive. By the time lunars had been developed, the HBC had not lost a ship through navigational mishap (as distinct from ice) for over forty years. The expense of the instruments and the challenge of having three skilled observers were additional reasons. But more important, the exact longitude of the ship, by itself meant little. To be of value, both the position of the ship and the established positions, variously points of departure and destinations, had to be known to a similar standard of accuracy. On the HBC routes to the Bay, this was not the case.

The quick adoption by HBC masters of reflecting instruments, and their comparatively fast use of mathematical methods for calculating offer evidence that these men were near the top of their profession. Certainly they had the necessary education to be comfortable with the latitude calculations. A comparison of HBC and Royal Navy pay scales suggests that the HBC paid well to get skilled men.

The HBC set new rates of pay on 22 February 1770 . The base salary was $£ 12$ per month for $£ 144$ a year. To that was added a gratuity of $£ 100$ for completing the voyage in a season, rather than wintering over in the bay. (The last time a ship had failed to make the return voyage in the same season had been in 1715 when the Port Nelson, James Belcher, went to Albany in the southern half of James Bay.) To compensate for the company's strictly enforced rule of not allowing any private trade, otherwise a normal privilege in merchant shipping circles, masters were also allowed $£ 5 / 5 /$ - in lieu of presents offered at factories, and the same for looking after the company's affairs in London. Finally, in addition to this total compensation of $£ 255$, there was, a gratuity of $1 / 6$ [one shilling and sixpence] per score of made beaver after the annual sales. ${ }^{79}$ This compares very well with the pay of a naval captain. The Royal Navy's scale of pay in effect for almost the entire eighteenth century, varied according to the size of ship. Constrained by the size of the rivers on which the trading posts were located, even the largest of the company's ships would have been smaller than a navy's sixth rate, length 107 feet and beam 30 feet

\footnotetext{
${ }^{78}$ Wales, 116.

${ }^{79}$ London committee minutes, A1/139, microfilm 17, HBCA.
} 
4 inches. ${ }^{80}$ At sea, the captain of a sixth rate or smaller ship would receive $£ 8 / 8 /$-per lunar month or $£ 109 / 4 /-$ annually. Unemployed, the half pay would have been $£ 54 / 12 /$ - per annum. At sea a captain could also draw a variety of allowances, but set against all that was the fact that pay was normally at least one year in arrears. ${ }^{81}$ The company's pay scale was modified in April 1786. Both chief and second mates were to be paid "by the year of twelve calendar months" at $£ 6$ and $£ 5$ per month respectively. Additionally, the six mates of the three ships were to share equally a bounty of "one shilling upon every score of made beaver that shall be brought home." $" 82$

Over the course of the eighteenth century the HBC achieved an enviable record of safe voyages. That may be attributed to an increasing standard of education and skill amongst its masters, and the mates from whose ranks most of them were promoted. The "seeming tardiness" of HBC masters in adopting new methods of determining longitude was governed by the apparent lack utility of the improved information. To improve navigational accuracy, the masters were quick to adopt better instruments and methods for finding latitude. On the question of the importance of being able to find longitude at sea, Jonathan Fowler might be given the final word. Even after the lunar distance method had been developed and simplified, Fowler still said of calculated latitudes, "I really think it the greatest help $\&$ improvement in navigation that has been made Publick since I have used the Sea."

\footnotetext{
${ }^{80}$ E.H.H. Archibald, The Wooden Fighting Ship in the Royal Navy AD 897 - 1860, (New York, 1968), 50. This was a twenty-eight gun frigate. Dove provides an extensive discussion of the HBC ships in his chapter three.

${ }^{81}$ N.A.M. Rodger, The Command of the Ocean: A Naval History of Britain, 1649 - 1815, (London, 2004), 623.

${ }^{82}$ London committee minutes, 12 April 1786, A1/46, microfilm 6, HBCA.
} 